\title{
ArcheoSciences
}

Revue d'archéométrie

33 (suppl.) | 2009

Mémoire du sol, espace des hommes

\section{Magnetic survey of the Late Period grate temple enclosure in Tell el-Balamun, Egypt}

\section{Tomasz Herbich}

\section{Q OpenEdition \\ 1 Journals}

\section{Electronic version}

URL: https://journals.openedition.org/archeosciences/1323

DOI: 10.4000/archeosciences.1323

ISBN: 978-2-7535-1599-4

ISSN: 2104-3728

Publisher

Presses universitaires de Rennes

\section{Printed version}

Date of publication: 30 October 2009

Number of pages: $77-79$

ISBN: 978-2-7535-0943-6

ISSN: 1960-1360

\section{Electronic reference}

Tomasz Herbich, "Magnetic survey of the Late Period grate temple enclosure in Tell el-Balamun, Egypt", ArcheoSciences [Online], 33 (suppl.) | 2009, Online since 30 October 2011, connection on 01 February 2022. URL: http://journals.openedition.org/archeosciences/1323 ; DOI: https://doi.org/ 10.4000/archeosciences.1323 


\title{
Magnetic survey of the Late Period grate temple enclosure in Tell el-Balamun, Egypt
}

\author{
Tomasz Herbich*
}

key words: Magnetic method, Egypt, Nile Delta, Late Period, Mud-brick architecture.

Tell el-Balamun lies at the northern edge of the Delta, close to where the eastern branch of the Nile empties into the Mediterranean and it was the northernmost town of Pharaonic Egypt. Explored on and off in the early 20th century and the 1970s, it has been since 1991 the object of investigation by an expedition led by J.A.Spencer and sponsored by the British Museum. Work has focused on a temple complex surrounded by enclosure walls in the southern part of the site (Fig. 1). The plan and dating of the main features of this complex have become clear following excavations: temple of Amun (erected in the New Kingdom, rebuilt in the Late Period), temples of Psamtik I and Nectanebo I, a citadel in the southern corner of the enclosure (all of Late Dynastic date). Ptolemaic-period architecture was discovered in the northeastern part of the complex and Late Period burials located north of the Amun temple. The 30th Dynasty outer enclosure wall was traced thanks to surface vestiges of the foundations and its size was determined at 450 by $400 \mathrm{~m}$. The less well preserved wall of the 26th Dynasty was mapped in effect of the excavations.

The principal building material used on the site - dried bricks of Nile silt - is characterized by considerable magnetic susceptibility. Baked bricks are rare (limited to Roman-age structures). Stone must have been used in the monumental buildings, but the blocks appear to have been all lost to plunder once the original architectural function had ceased.

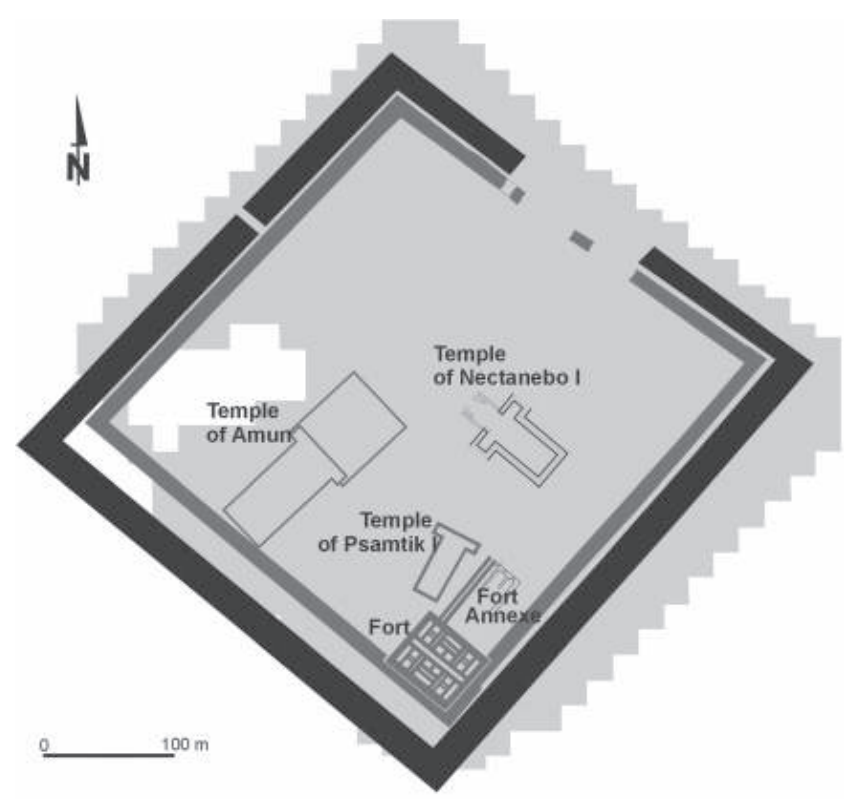

Figure 1: Tell el-Balamun, the great temple enclosure. In dark grey, the enclosure wall of the 26th Dynasty; in black, the enclosure wall of the $30^{\text {th }}$ Dynasty. The area of magnetic survey in transparent grey.

The size of the complex precluding extensive excavations of the area inside the enclosure wall suggested the use of geophysical methods of prospection. The survey, run as a

* Institute of Archaeology and Ethnology, Polish Academy of Sciences Al. Solidarnosci 105, 00-140 Warsaw, Poland. (tomasz.herbich@gmail.com) (herbich@iaepan.edu.pl) 
joint project of the British Museum and the Polish Center of Mediterranean Archaeology of the University of Warsaw, applied the geomagnetic method, which has been proven in the past ten years to be extremely effective on tell sites, that is, mounds created by accumulating cultural deposits. Measurements were taken with a fluxgate gradiometer with $0,1 \mathrm{nT}$ resolution in a grid enforcing eight measurements per square meter, grid squares being 20 by $20 \mathrm{~m}$. Data were collected in parallel mode with sensors adjusted at a reference point following completion of every single grid square. Between 2005 and 2008, a total of 21 ha was surveyed in this way. Data processing with Geoplot 3.0 software was limited to sporadic edge matching or desloping. No zero mean traverse and low pass function were applied.

Magnetic mapping provided a clear overall image of already excavated structures as well as bringing to light a number of unknown structures, including ones in apparently well-researched areas inside the temples and fort and in the northwestern part of the enclosure which had enjoyed little interest on the part of archaeologists so far.

The features most in evidence on the magnetic map are the sand fillings of temple foundations (Fig. 2). The outline of a

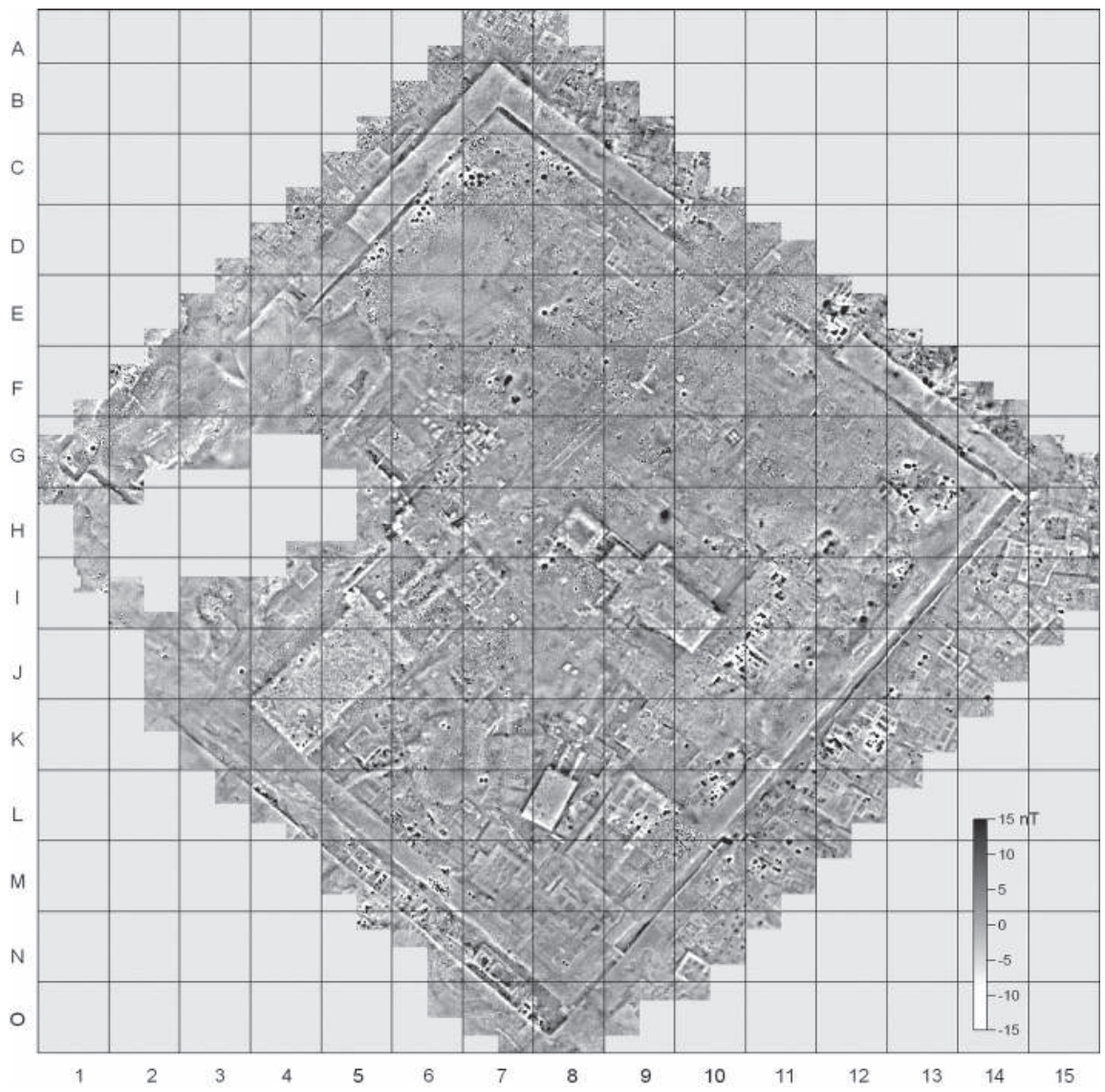

pylon just northeast of the Amun temple naos and a narrow colonnade foundation in front of it are also very distinct. A similar colonnade behind the entrance pylon was revealed in the temple of Psamtik I (in the southern part of square K8, Fig. 2). It also appeared, judging by the two parallel anomalies of lower magnetic value registered in front of the pylon (between NE part of K8 and SW part of J9) that the approach to the temple was more extensive than previously anticipated. There seem to have been structures lining the sides of a processional way leading to the temple.

The plan of the Nectanebo temple known from excavations is clearly reflected on the magnetic map. The square structure of low magnetic properties seen on the map in front of the temple (in H8, Fig. 2) turned out to be Balamun's apparently sole surviving stone building (Fig. 3). It was a bark-station. Around the rear of the Nectanebo temple prospection revealed remnants of a mud-brick wall with bastions on the exterior (in the eastern part of I10, Fig. 2). Judging by the magnetic map, this wall is cut by the back of the temple foundation, with parts surviving on either side (in I10 and J9-J10).
Figure 2: Magnetic map of the great temple enclosure at Tell el-Balamun. Fluxgate Geoscan Research FM36 and FM256 gradiometers. Sampling grid $0.25 \mathrm{~m}$ by $0.5 \mathrm{~m}$. Dynamics -9 nT (white)/+15 nT (black). Grid lines every $40 \mathrm{~m}$. 


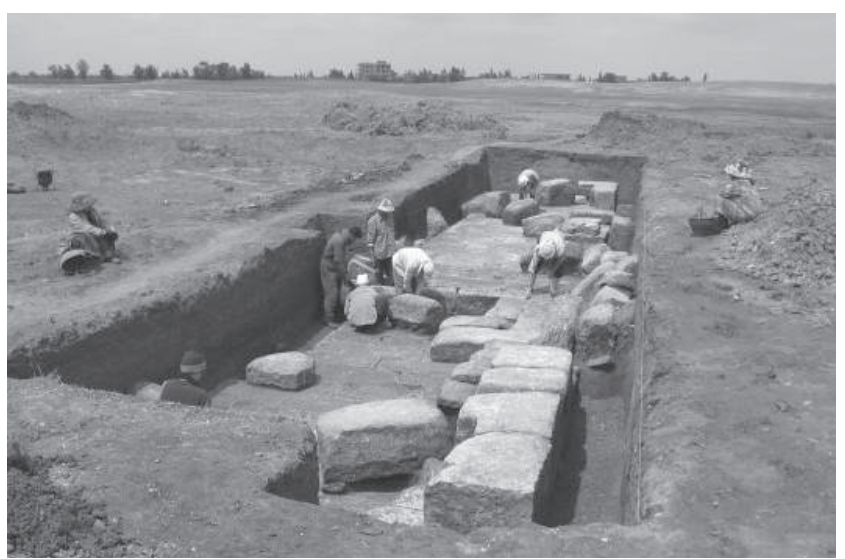

Figure 3: North-eastern side of the limestone foundation of the structure in front of the Nectanebo temple, seen from the northwest.

The less than distinct T-shaped structure oriented directly to the north, observed in squares K7, L7 and in the western edge of K8 (Fig. 2), was found to correspond to the outlines of a foundation-pit for an unknown temple. This mud-brick sanctuary had been destroyed so extensively that its tracing by traditional methods of archaeological excavation would not have been possible.

At some points the magnetic map revealed evidence of structures on multiple levels, as, for example in the building described as the Fort Annexe (Fig. 1). At the time of excavation, the southern part of this building turned out very difficult to trace chiefly because it had been partly overbuilt by a later structure of rectangular shape, with its longer dimension aligned NW-SE (seen in the NE part of M8, NW part of M9, SW part of L9, Fig. 2). The presence of the later structure proved far simpler to detect by magnetic mapping than through actual excavation.

In the area where digging uncovered Ptolemaic vestiges (in the northeastern part of the enclosure) the magnetic map has provided data for the reconstruction of the street grid in this district.

Geophysical mapping has also contributed to verifying the run of the outer enclosure wall of 30th Dynasty date.
The magnetic image of the northeastern and northwestern wall sections reflects its method of construction as separate, projecting and recessed, panels of brickwork. In places where erosion had obliterated the wall entirely (the southeastern section), the map evinces the presence of casemate-type buildings probably from the Saite Period. Since the inner wall shows less clearly on the surface than the outer wall, the magnetic survey has provided valuable information on the alignment and thickness of this wall at various points. A gate has also been identified in the southeastern section of the wall from the 26th Dynasty (in the SW corner of K11).

Data from the magnetic survey has pinpointed areas of industrial activity inside the enclosure, for example, concentrations of furnaces at the back of the Nectanebo temple and in the northern corner of the enclosure. An industrial complex was also observed sandwiched between the southwestern sections of the 26th and 30th Dynasty enclosure walls (between the NE parts of M5 and O7), proving that the two walls had coexisted at least for a while.

The results of the Balamun prospection have confirmed yet again the efficiency of magnetic surveying in the investigation of mound sites in the Delta. Indeed, it can be said without exaggeration that geophysical research is becoming increasingly a prerequisite tool in preparing for the archaeological excavation of such tell sites.

\section{References}

Spencer, A. J., 1996. Excavations at Tell el-Balamun 1991-1994, London, British Museum Press.

Spencer, A. J., 1996. Excavations at Tell el-Balamun 1995-1998, London, British Museum Press.

Spencer, A. J., 1996. Excavations at Tell el-Balamun 1999-2001, London, British Museum Press.

Herbich, T., Spencer, A. J., 2006. Geophysical survey at Tell elBalamun, Egyptian Archaeology,29 (Autumn): 16-19.

Herbich, T., Spencer, A. J., 2007. Tell el-Balamun: Geophysical and archaeological survey, 2005, Reports 2005, Polish Archaeology in the Mediterranean, 17, 117-123. 